\title{
Impact of Benchmarking to Applied the Strategic Cost Methods
}

(Field Study in Paints Companies - Khartoum State)

\author{
Dr. Abubkr Ahmed Elhadi Abdelraheem \\ Associate Professor - Department of Accounting \\ Faculty of Managerial and Financial Sciences - Peace University - Sudan \\ Dr. Badreldin Elhadi Ahmed Serajeldin \\ Associate Professor, Department of Accounting \\ Faculty of Managerial and Financial Sciences, Peace University, Sudan \\ Aldouma Abdallah Abdalrahman Jedo \\ Lecturer, Department of Accounting \\ Faculty of Managerial and Financial Sciences, Peace University, Sudan
}

\begin{abstract}
This study aimed to identify the Impact of benchmarking to Applied the strategic cost methods in paints companies - Khartoum state, the study tested two hypotheses which are: there are statistically significant relationship between Applied the benchmarking and activating the strategic cost methods, there are statistically significant relationship between Applied the benchmarking and rationalizing administrative decisions. Researchers distributed (60) questionnaire forms among some of the workers in the field selected randomly (57) Forms were collected as $95 \%$. (SPSS) used for analyzing data. The study reached some findings from which: the benchmarking Contribute in applied the strategic cost methods with high efficiency by benefiting from the experiences of competitors, the benchmarking Contribute in to assist management in decision-making for reducing the costs of production in paints companies - Khartoum state. the study recommended to: taking advantage of comparative measurement and methods of strategic cost in responding to competition by controlling cost element.
\end{abstract}

Keywords: Benchmarking, Strategic Cost Methods

\section{Introduction}

In light of the severe competition faced by industrial companies, the traditional cost system is no longer capable of satisfying the wishes of the management of the necessary information to deal with competition. In order for industrial companies to continue in the field of business, the modern systems and tools that help

management in cost planning and control during the life cycle This study focuses on comparative measurement and its impact on the application of the strategic cost methods of the companies of the paint in the state of Khartoum.

\section{The problem}

Is the inability of traditional cost methods to adapt to the conditions of intense competition of companies and the diversity of customer needs? The study was designed to investigate the impact of benchmarking on applied the strategic cost methods and streamlining administrative decisions on cost reduction and competition.

\section{The Objectives:}

The study aims to identify the concept of strategic cost and its methods and the concept of benchmarking.

\section{Hypotheses:}

$>$ There is a statistically significant relationship between benchmarking and applied the strategic cost methods.

$>$ There is a relationship of statistical significance between benchmarking and rationalization of administrative decisions. 


\section{Benchmarking concept}

benchmarking is the process of comparing the cost and time of an organization with another organization in the same industry in order to improve the performance of industrial organizations and access to best practices for competitors, and the comparison must be continuous (Ashok K,2010) ${ }^{1}$.benchmarking is a way to learn from others and gain experience to reach successful ideas, a way to create a competitive advantage by comparing the operations of an establishment and its activities with competitors (Edward,2002) ${ }^{2}$, benchmarking is a systematic and continuous process to measure and compare a company's industrial or commercial operations with its competitors anywhere in the world to obtain information that helps the company take the necessary measures to improve its performance(Jens $\mathbf{J}$ et all,2002) ${ }^{3}$. and the process of benchmarking consists of five steps(Salim,2010) ${ }^{4}$ :

$>$ Plan: - where the critical factors and elements of success in the establishment and the selection of processes and documents and performance measures to which the benchmarking is applied.

$>$ Identify partners: Where the search for benchmarking partners, any competing enterprises Has successful market experiences.

$>$ Collection of information: where information about the documents, processes and performance of the partners is collected in relation to the critical success elements identified in the plan.

$>$ Analysis of information: where the gap in performance between the establishment and other establishments and identify the causes.

$>$ Application: Where the facility is configured to change, and apply best practices according to benchmarking .

\section{Strategic Cost Concept}

The strategic cost is the use of cost-management information for the stages of the four-strategic management cycle, which consists of the formulation and composition of the strategies, the stage of communicating the strategies to the different administrative levels, the stage of implementation of the strategies and the stage of designing and implementing a system for monitoring the steps of implementing the strategy to help the management in making decisions (Shank,1989) ${ }^{5}$.
Strategic cost is to use cost data and mix it with the strategic objectives of the organization to maximize competitive advantages (Don $\mathbf{R}$ et all ,2006) ${ }^{6}$.

Strategic cost is a cost structure analysis in the light of enterprise strategies to help management make decisions (Shannon W,2005) ${ }^{7}$.

Strategic cost is a description of cost management by focusing on issues strategy (Charles T et all,2012) ${ }^{8}$.

\section{Strategic Cost Methods}

(Al-Arifi,2010) ${ }^{9}$ identified the strategic cost methods as follows:Just in Tim,Flexible Manufacturing System, Target costing, Activity Based Costing, Value Chain Analysis, Kaizen Cost. and (El Kelety, 2006) ${ }^{10}$ identified the strategic cost methods as follows: Target costing, Activity Based Costing, life cycle Costing.

\section{Results \& Discussion:}

Sample and study tool: The study population is represented in the paint in Khartoum state. The sample of the study includes all the employees in paint Company for randomly selected. (60) questionnaire forms among some of the workers in the field selected randomly (57) Forms were collected as $95 \%$ and the Table (1) shows this.

Table (2) that the median of all the answers of the respondents on the first hypothesis is (4), and Through the median researcher observes that all of the sample agree with the hypothesis phrases, and a level of significance Chi square (.000) less than the significance level 0.05 , This confirms the existence of a statistically significant relationship between benchmarking and applied the strategic cost methods.

Table (3) that the median of all the answers of the respondents on the second hypothesis is (4). and Through the median researcher observes that all of the sample agree with the hypothesis phrases, and a level of significance Chi square (.000) less than the significance level 0.05 . This confirms the existence of is a statistically significant relationship between benchmarking and rationalization of administrative decisions. 
International Journal of Trend in Scientific Research and Development, Volume 1(4), ISSN: 2456-6470 www.ijtsrd.com

Table (1)

\begin{tabular}{|c|c|c|c|}
\hline Company name & Distributed & Recovered & Percent \\
\hline Ayoub & 12 & 12 & $100 \%$ \\
\hline Elmhandis & 12 & 12 & $100 \%$ \\
\hline Soldor & 12 & 10 & $83 \%$ \\
\hline Elmosharaf & 12 & 12 & $100 \%$ \\
\hline Al Jazeera & 12 & 11 & $92 \%$ \\
\hline Total & $\mathbf{6 0}$ & $\mathbf{5 7}$ & $\mathbf{9 5 \%}$ \\
\hline
\end{tabular}

Table (2) Median \& Chi-Square

\begin{tabular}{|l|l|l|l|}
\hline \multicolumn{1}{|c|}{ Phrase } & Median & Chi-Square & Asymp. Sig \\
\hline $\begin{array}{l}\text { The benchmarking method helps to activate the cost of the } \\
\text { product life cycle by taking advantage of the competitors' } \\
\text { experiences in determining the methods used in accounting } \\
\text { for the life cycle costs of the product. }\end{array}$ & 14.424 & 0.006 \\
\hline $\begin{array}{l}\text { The benchmarking method helps to activate cost-based } \\
\text { activity by taking advantage of competitors' experience in } \\
\text { determining target cost and target profit. }\end{array}$ & 4 & 10.485 & 0.033 \\
\hline $\begin{array}{l}\text { The benchmarking method helps to activate quality costs by } \\
\text { taking advantage of the competitors' experience in } \\
\text { determining the structure of cost of quality and the method } \\
\text { of classification. }\end{array}$ & 4 & 23.515 & 0.000 \\
\hline $\begin{array}{l}\text { The benchmarking method helps to activate the costs of } \\
\text { continuous improvement by taking advantage of } \\
\text { competitors' experiences in determining the methods used } \\
\text { in developing the performance of employees, increasing } \\
\text { their motivation and developing the performance of } \\
\text { machinery and equipment. }\end{array}$ & 4 & 21.697 & 0.000 \\
\hline $\begin{array}{l}\text { The benchmarking method helps to activate the cost based } \\
\text { on the activity by taking advantage of competitors' } \\
\text { experiences in determining the cost in the production stage. }\end{array}$ & 4 & 15.030 & 0.005 \\
\hline $\begin{array}{l}\text { The benchmarking method helps to activate production on } \\
\text { time while benefiting from competitors' experiences in } \\
\text { determining the lowest cost of storage. }\end{array}$ & 4 & 12.909 & 0.012 \\
\hline
\end{tabular}


Table (3) Median \& Chi-Square

\begin{tabular}{|l|l|l|l|}
\hline \multicolumn{1}{|c|}{ Phrase } & Median & \multicolumn{1}{|c|}{$\begin{array}{c}\text { Chi- } \\
\text { Square }\end{array}$} & $\begin{array}{c}\text { Asym } \\
\text { p. Sig }\end{array}$ \\
\hline $\begin{array}{l}\text { Benchmark method is concerned with rationalizing management decisions } \\
\text { to confront competition by seeking the best practices of competitors. }\end{array}$ & 4 & 19.576 & 0.001 \\
\hline $\begin{array}{l}\text { Benchmark method rationalizes management decisions to increase product } \\
\text { quality by learning with competitors in the market. }\end{array}$ & 4 & 12.303 & 0.015 \\
\hline $\begin{array}{l}\text { Benchmark measurement method rationalizes management decisions to } \\
\text { reduce the cost of the product life cycle by comparing with competitors in } \\
\text { the market. }\end{array}$ & 4 & 10.182 & 0.037 \\
\hline $\begin{array}{l}\text { Benchmarking method contributes to the rationalization of management } \\
\text { decisions for continuous improvement of all plant activities and operations. }\end{array}$ & 4 & 14.727 & 0.005 \\
\hline $\begin{array}{l}\text { The benchmarking method contributes to customer satisfaction. } \\
\text { Benchmarking method works to achieve the competitive advantages of the } \\
\text { company. }\end{array}$ & 3 & 10.758 & 0.013 \\
\hline
\end{tabular}

\section{Findings}

$>$ Benchmarking Contribute in applied the strategic cost methods with high efficiency by benefiting from the experiences of competitors.

$>$ Benchmarking Contribute in to assist management in decision-making for reducing the costs of production in paints companies Khartoum state.

\section{Recommended}

Taking advantage of comparative measurement and methods of strategic cost in responding to competition by controlling cost element.

\section{References:}

1 - Ashok K Agarwal,(2010), Cost Accountants for Growth of SME Sector, The Management Accountant, Volume 45 No. 5, P 373.

2 - Edward Sallis, (2002), Total QualityManagement inEducation, London, Kogan Page Ltd, P 99.

3 - Jens J. Dahlgaard, Kai Kristensen and Gopal K. Kanji, (2002), Fundamentals of Total Quality Management - Process Analysis and Improvement, London, Taylor \& Francis, P179.
4 - Ahmed Hashim Moawad Salim, (2005), Using Comparative Measurement Method for Cost Management in Support of Competitive Advantage of the Corporation, Egyptian Journal of Commercial Studies, Faculty of Commerce, Mansoura University, Volume 29, No. 2, p. 237.

5 - John K. Shank, (1989) Strategic Cost Management: New Wine or Just New Bottles, Journal of Management Accounting Research, Volume (1), P. 50 .

6 - Hansen Don R. \& Maryanne M. Mowen, (2006), Cost Management Accounting and Control, $5^{\text {th }}$ ed (Thomson, South Western,). p.486.

7 - Anderson, Shannon W, (2005) Managing Costs and Cost Structure Throughout the Value Chain, Research on Strategic Cost Management, Rice University, $\mathrm{p} 2$.

8 - Horngren, Charles T. \& Srikant M. Datar \& Madhave V. Rajan,( 2012) Cost Accounting: A Managerial Emphasis, $14^{\text {th }}$ ed (New Jersey: Prentice Hall,), p 5.

9 - Fouad Ahmed Mohammed Al-Arifi,(2010), An Integrated Approach to Cost Management in the Competition of Industrial Companies, Presented at the 12th Symposium on Accounting Development in the 
Kingdom of Saudi Arabia, under the theme of Accounting Profession in Saudi Arabia and the Challenges of the 21st Century, College of Business Administration, King Saud University. Pp. 17-18.

10- Ibrahim Abd El Mageed Ali El Kelety,(2006), Towards a Conceptual Framework for Strategic Cost Management, Chemnitz University of Technology, $p$ 66 . 